\title{
Synthesis of Aniline - Pyrrole Copolymer Nanostructures by the Pulsed Galvanostatic Polymerization
}

\author{
Hassan Karami ${ }^{1, *}$, Samaneh Jafari ${ }^{2}$, Fariba Goli $^{2}$ \\ ${ }^{1}$ Department of Chemistry, Payame Noor University, 19395-4697, Tehran, I.R. of Iran \\ ${ }^{2}$ Nano Research Laboratory, Department of Chemistry, Payame Noor University, Abhar, Iran \\ *E-mail: karami_h@yahoo.com
}

doi: $10.20964 / 110403056$

Received: 18 November 2015 / Accepted: 6 February 2016 / Published: 1 March 2016

In this work, aniline- pyrrole copolymer (APC) nanoparticles are synthesized by the pulsed galvanostatic polymerization method. Two cylindrical platinum grid electrodes with diameters of 1 and $3 \mathrm{~cm}$ are used as coaxial in the electrochemical cell containing aniline, pyrrole and $\mathrm{HCl}$ solution. Aniline and pyrrole are directly oxidized to aniline and pyrrole cation radicals as polymeric precursors on the surface of platinum anode. The effects of synthesis parameters such as pulsed current value, pulse time $\left(\mathrm{t}_{\mathrm{on}}\right)$, relaxation time $\left(\mathrm{t}_{\text {off }}\right)$, temperature and concentrations of aniline, pyrrole and hydrochloric acid are studied and opimized by the "one factor at a time" method. The optimized conditions include $0.1 \mathrm{M}$ pyrrole, $0.1 \mathrm{M}$ aniline and $0.12 \mathrm{M}$ hydrochloric acid, $9 \mathrm{mAcm}^{-2}$ current density, $1 \mathrm{~s} \mathrm{t}_{\mathrm{on}}, 1 \mathrm{st}_{\text {off }}$ and solution temperature of $1^{\circ} \mathrm{C}$. The synthesized nanomaterials are filtered and washed with $0.12 \mathrm{M}$ hydrochloric acid solution and finally washed with double- distilled water. The obtained precipitate is dried at $80^{\circ} \mathrm{C}$ for $90 \mathrm{~min}$ under vaccum. The synthesized samples are characterized by SEM, TEM, DLS, TGA/DTA, IR spectroscopy, UV- Vis spectroscopy and Cyclic Voltammetry. The final sample consisting spherical nanoparticles with mean diameter smaller than 10 $\mathrm{nm}$.

Keywords: Polymer nanoparticles, aniline- pyrrole copolymer, electropolymerization, pulsed galvanostatic method

\section{FULL TEXT}

(C) 2016 The Authors. Published by ESG (www.electrochemsci.org). This article is an open access article distributed under the terms and conditions of the Creative Commons Attribution license (http://creativecommons.org/licenses/by/4.0/). 